\title{
Determinants of Pension Governance: A Survey of Pension Plans in Kenya
}

\author{
Amos Gitau Njuguna \\ Assistant Professor of Accounting \& Finance, United States International University \\ P.O. Box 14634-0800 Nairobi, Kenya \\ Tel: 254-20-360-6204/254-7255-1653E-mail: amnjuguna@usiu.ac.ke
}

Received: April 15, 2011

Accepted: June 7, $2011 \quad$ Published: November 1, 2011

doi:10.5539/ijbm.v6n11p101

URL: http://dx.doi.org/10.5539/ijbm.v6n11p101

\begin{abstract}
Pension governance is acknowledged as a vital characteristic of a proficient private pension system as it determines the investment performance, operational efficiency and the security of pension benefits. Empirical literature shows that despite the legal and industry inventiveness, pension governance lapses continue across countries. This paper investigates the determinants of pension plan governance in Kenya and recommends measures that can strengthen it. The sample consists of 362 pension plans in Kenya. Statistical tests are conducted by use of Pearson correlations, regressions, Scheffé tests and Analyses of variance (ANOVA) to determine the effect that pension regulations, pension plan design, membership age, number of members in the pension plan and plan leadership, have on pension governance. Empirical results show that pension governance is influenced by pension regulations, leadership, and membership age. The pension plan design and number of members do not have significant influence on how the pension plans are governed.
\end{abstract}

Keywords: Pension governance, Pension leadership, Pension regulations

\section{Introduction}

Funded pension systems have in the recent past gained popularity since they contribute to the economic growth of countries worldwide through direct contribution to the GDP (Watson, 2007; Corbo and Schmidt-Hebbel, 2004), accumulation of savings (Rauh, 2006; EBRI, 2007), financial market development (Davis, 2005; Yermo, 2008), reducing old-age poverty (Kakwani, Sun and Hinz, 2006) and acting as consumers of financial services (Heijdra, Ligthart and Jency, 2006). The growth of funded pension systems has led to the increase in domestic savings in Africa. Dovi (2008) documents that between 1998 and 2007 the savings increased from 17.8\% to $22.1 \%$ of the GDP in Sub-Saharan Africa and from 21\% to 30\% of the GDP in Northern Africa as a result of embracement of the funded pension systems. The pension system has further reduced the poverty trap ratio by $13 \%$ in South Africa and increased the income of the poorest 5\% by 50\% (Stewart and Yermo, 2009). In Kenya, the pension system contributes to an estimated $68 \%$ of the total income of retirees (Kakwani et al, 2006) and controls wealth estimated at Ksh. 397 billion, the equivalent of 30\% of the country's GDP (RBA, 2010).

Proper governance of funded pension systems leads to continuous improvement by ensuring that pension plans regularly review their governance structures for operational risks, internal controls and compliance with appropriate legislations (Ambachtsheer, 2001; Clapman et al, 2007; Besley and Prat, 2005; Impavido, 2005; Clark and Urwin, 2008; Asher and Nandy, 2006; Galer, 2009). It also ensures that the pension plan has the structures and processes in place to meet the required standard of fiduciary care and proper documentation of the due diligence (Moriarty and Zadorozny, 2008), improves performance of the pension plan, creates trust amongst the stakeholders and is vital to the efficient functioning of the private pension systems (Stewart, 2009) in addition to improving administrative efficiency (OECD, 2009). Inadequate pension governance mechanisms result to poor, inefficient and irrational decisions that increase the costs of operating pension plans.

The need to study pension plan governance is motivated by the fact that the pension system plays a critical role not only in providing channels for retirement savings but also as financial market intermediaries, which subject them to potential conflicts of interests arising between the beneficiaries and the fund administrators. Whereas pension system beneficiaries hope to maximize their long-term wealth, the administrators pursue short term goals and hence fail to act in the best of the interests of the beneficiaries creating an agency issue. Besley and Prat (2005) documented the application of the agency theory in private pension fund governance, Hess and Impavido (2003) argued its application in the public pension system while other studies (Impavido, 2005; Ambachtsheer, Capelle and Lum, 2006; Dias, 2006; Clapman et al, 2007; Ambachtsheer, Capelle and Lum, 2008; Rusconi, 2008; Stewart and Yermo, 2008) have focused on the inadequacies of pension governance. This study contributes to the knowledge on pension governance by investigating the factors that account for pension governance in a developing country - Kenya. 


\section{Literature Review}

Governance is defined in Carmichael and Palacios (2003) and IOPS (2007) as the "systems and processes by which a company or government manages its affairs with the objective of maximizing the welfare of and resolving the conflicts of interest amongst its stakeholders." The authors thus suggest that pension governance is about transparency, conflict resolution and prudent management of the organizational resources that contribute to value addition. Qureshi and McKay (2007) identify three broad approaches of viewing pension governance in the context of multi-national companies namely; decentralized governance where the pension governance is exercised in different pension plans in the same country, compliant governance, which implies following the law and efficient governance, which refers to making financial and operational efficiency gains. Qureshi and McKay (2007) recommend the efficient governance option as it acts as a complacence to the other approaches. In other words, efficient governance should enable the pension plan to achieve compliance with the pension law and control of the decentralized units that eventually contributes to increased efficiency in operations.

Effective pension governance ensures that potential conflicts of interests arising between the pension plan administrators and the ultimate beneficiaries of the fund are solved amicably (Stewart, 2009; Useem and Mitchell, 2000; Yang and Mitchell, 2005; Yermo, 2008). Accordingly Teisseire (2009) and Clark (2006) conclude that pension governance defines accountabilities, establishes authority levels, specifies mechanisms of enhancing compliance with the law and enables provision of accurate, timely and reliable financial information to the stakeholders.

Empirical studies find serious pension governance lapses across the world. Stewart and Yermo (2008) document the ineffectiveness of the pension governance body in Hungary in enforcing stakeholder's rights, Clapman et al (2007) show evidence of the lapses in USA, Ambachtsheer et al (2006) document the same problem in Australia, Canada, New Zealand, UK and USA, Dias (2006) disclose the problem in Brazil and Rusconi (2008) unveil the problem in South Africa. While the studies address the prevalence of pension governance lapses, the present study addresses the determinants of pension governance with a view of improving such governance in Kenya.

\subsection{Pension Governance Structures}

A pension plan's governance structure defines and separates operational and oversight responsibilities of the stakeholders (OECD, 2009). As such the responsibilities of the internal trustees, external trustees and members should be clearly stipulated in the trust deed. The separation of duties should reflect on the risks that the pension plan is exposed to. Moreover, pension plans should have governing bodies charged with the responsibility of managing the pension plan and the protection of the best of the interests of the beneficiaries (RBA, 2010). OECD (2009) recommends a two-tier board involving a managing and a supervisory board. Principally, the governing board should have member nominated trustees, sponsor nominated trustees, a custodian, an actuary, a fund manager and a fund administrator while the supervisory board should be composed of persons independent of the governing board. All the members in the board should have clearly articulated responsibilities with well documented means of solving conflicts of interests amongst themselves. The governing board should be accountable to the pension plan members, beneficiaries and the regulating authorities. The membership to the board should be subject to minimum suitability standards of integrity, competence, experience and professionalism in the governance of the pension plan (OECD, 2009). The governance structure is vital because the pension plan beneficiaries and the administrators do not have the same contractual ability in terms of skills, knowledge and information (Hess and Impavido, 2003). RBA (2010) lists the responsibilities of the governing board as;

- Setting out pension plan's goals, mission, policies and creation of a reflective investment strategy;

- Monitoring administration of the pension plan to ensure that key objectives are achieved;

- Selecting and remunerating external trustees

- Ensuring that the pension plan complies with the law

- Monitoring performance of the pension plan's investment

- Sending appropriate and timely communication to members of the pension plan.

\subsection{Code of Governance for Pension Plans}

Governance entails four main tenets namely; leadership (setting the strategic direction of the organization and setting up structures to accomplish the objectives), stewardship (guarding resources that belong to others), monitoring (receiving and reviewing measures of performance and hold the assignees accountable) and reporting (accounting to the principals). Attempts to develop a governance code for pension funds have revolved around these tenets. The initiatives include Clapman et al (2007); Ambatchsheer (2007) and CFA (2008). In summary, key specifics that emerge from the initiatives forming the code of governance for pension systems are; board composition, leadership, continuous education of the board, liability insurance for the board, avoidance of conflicts of interest, communication with the stakeholders, formulating and implementing effective systems of control, monitoring the performance of service providers, clear definition of roles of the stakeholders, outsourcing key functions and having a performance measurement system.

\subsection{Hypothesized Model to Improve Pension Plan Governance}

Pension plans receive inputs (scarce financial resources in the form of contributions from members and investment funds) and convert these inputs to outputs (pension fund value and retirement benefits) (Davis, 2005). 
Pension governance should therefore aid in the efficient transformation of the pension fund incomes to retirement benefits and high asset values. The study conceptualizes pension governance as the end result of adherence to pension regulations, leadership, choosing the appropriate pension design, managing the age profile of the members as well as the number of members covered by the plan. This conceptual framework is graphically illustrated in Figure 1.

\subsubsection{Relationship between Pension Regulations and Governance}

$\mathrm{Hu}$, Stewart and Yermo (2007) and Madero and Lumpkin (2007) find that pension governance improved significantly in all the OECD countries as a result of implementation of quantitative asset restriction and the prudent person laws. The quantitative asset restriction, legislated on the maximum percentages that could be invested in specific classes of assets while the prudent person rule legislated on a code of governance (Hu et al, 2007). Moreover, $\mathrm{Hu}$ et al (2007) showed that in China, pension regulations resulted in more robust risk control mechanisms, better investor protection, more transparent information disclosure and subsequent stability of the pension plans.

Eijffinger and Shi (2007) attribute pension governance crises in the European Union to regulatory failure. The crises have made pension plans inefficient and unable to deliver on their promises to the stakeholders and so pension laws should be created in licensing, governance, asset restrictions, financial information disclosures and guarantees (Clark, 2005; Eijffinger and Shi 2007). Similar views are documented in Clark (2006) and IOPS (2007). Additionally, Clark (2006) found that legislation on pension design; financial reporting and service providers improved governance. IOPS (2008) and Odundo (2008) conclude that adoption of risk-based supervision in the pension industry leads to improved governance. These arguments lead to the following hypothesis.

H1: Adherence to pension regulations exerts a positive influence on pension plan governance.

2.3.2 Relationship between Pension Design and Governance

Empirical literature suggests that pension plans operated on defined contribution ideologies are better governed than those that are operated on defined benefit principles because;

- They involve members more in decision-making (Hess and Impavido, 2003; Choi Laibson and Madrin, 2006; Bateman and Mitchell, 2004);

- The investment risk is borne by the members and not the sponsor hence members take all possible measures to avoid loss (Brady, 2008);

- There is lesser sponsor influence since the sponsor does not nominate majority of the members (Yang, 2005) and

- There is more transparency in decision-making and communication to members (Nyce, 2005; Clark and Mitchell, 2005).

It is therefore hypothesized that:

H2: Pension plans operated on the defined contribution design are better governed than those operated on defined benefit design.

\subsubsection{Relationship between Membership Age and Pension Governance}

The age of employees determines the pension promises that their employers will make to them since younger employees have a longer time horizon to invest compared to the older employees (Friedberg and Webb 2004; Lusardi and Mitchell, 2008) which in turn influences the type of pension design on which to anchor the pension plan. The studies point to a negative relationship between membership age and pension governance since employers prefer to establish defined benefit pension plans for older workers. It is therefore hypothesized that:

H3: The age of members exerts a negative influence on pension plan governance.

\subsubsection{Relationship between Number of Members in a Pension Plan and Governance}

Organizations with more members are difficult to manage and therefore require a more conservative governance style that may include increasing management levels and decentralization (Clark and Urwin, 2008). Additionally, communication in large organizations becomes expensive and ineffective thus leading to information asymmetry amongst the members of the organization (Teisseire, 2009). The information asymmetry impacts on the effectiveness of the members in contributing to decision making and running of the pension plans. The number of members in a pension plan has direct implications for pension governance as it influences the administrative efficiency and efficiency of the communication strategy (OECD, 2009; Carmichael and Palacios, 2003; Hustead, 2008). The empirical literature thus suggests a negative relationship between the number of members and governance. It is therefore hypothesized that:

H4: The number of members in a pension plan exerts a negative influence on pension governance.

\subsubsection{Relationship between Pension Plan Leadership and Pension Governance}

Pension leadership influences the way the pension plan is governed (Friedberg and Webb, 2004; Lerner, Schoar and Wongsunwai, 2007) since all pension plan management issues revolve around leadership. Similar findings are included in Clark and Urwin (2009) who in addition assert that the leaders of a pension plan are trustees who should bear responsibility for governance lapses. It is therefore hypothesized that: 


\section{H5: $\quad$ Pension plan leadership exerts a positive influence on governance.}

\section{Research Methodology}

\subsection{Measuring Instruments}

Instruments were developed to measure the variables identified from the empirical studies as having influence on pension governance. It was important to develop instruments that reflect the pension plan environment of Kenya. The instruments included pension governance, pension regulations, pension leadership, pension design, number of members in the pension plan and the age of the members in the pension plan.

The instrument that measured pension governance, rated the importance of the following pension plan governance constructs documented in the guidelines to pension plan management in Kenya; reducing the benefits processing period, continuous finance education to trustees, pension plan using an effective internal control system of documenting, monitoring and reporting its operations, effective communication to pension plan members, clearly defining the roles of trustees, competitively reviewing the fees payable to service providers and basing investment strategies on market research findings. The five-point anchoring scale for these indicators ranged from (1) not important at all, to (5) a great deal important.

An instrument was constructed to capture the important pension regulations to which Kenyan pension plans need to comply. The respondents were asked to indicate the importance of these regulations in the governance and regulatory environment of pension plans in Kenya. These regulations included: regular monitoring of performance of service providers, regulation of compliance costs by the Retirement Benefits Authority, limitation of the size of the board of trustees to 10, regulatory meetings, separation of the employer's business from the pension plan and preparation of a mandatory investment policy for the pension plans. The five-point anchoring scale for these indicators ranged from (1) not important at all to (5) a great deal important.

An additional instrument was constructed to capture the important leadership aspects applicable to the pension plans in Kenya. These elements included complete honesty when sharing information with members, CEO leaderships, maintaining an effective performance measurement system, compliance with the pension law relating to payment of levies, financial reporting and giving discretion to the pension plan managers. The self constructed instruments recorded final Cronbach Alpha values of 0.56, 0.52 and 0.61 for pension leadership, governance and regulations respectively. These values were considered acceptable for basic research (Pierce and Dunham, 1987; Tharenou, 1993; Saunders, Lewis and Thornhill, 2009).

The questionnaire also included instruments to capture variables such as pension plan design, number of members and membership age. The pension plan design instrument measured what type of design a pension plan has adopted, namely (1) defined contribution (DC) and (2) defined benefit (DB). The number of members in a pension plan was anchored to a six-point scale ranging (1) from less or equal to 100 to (5) more than 500 . The age of members was captured on a six-point scale ranging from (1) younger or equal to 20 years to (6) older than 60 years.

\subsection{Data Analysis}

Using a sample of 362 trustees of occupational pension plans in Kenya, various data analysis techniques were used to test the hypothesised relationships. Specifically, regression analysis, Pearson correlations, Scheffé tests and analyses of variance (ANOVA) were conducted using the STATISTICA Version 9.0 (2009) statistical software package.

\section{Results and Discussion}

The overall sample of 362 comprised; 316 trustees $(42.2 \%), 10$ chairpersons of the boards of trustees (1.3\%), 23 former trustees $(3.1 \%)$ and 13 trust secretaries $(1.7 \%)$. Table 1 depicts the demographical composition of the sample. Most of the respondents were male (81.8\%) and between 30 to 39 years old. Most of the respondents were also middle level managers $(96.5 \%)$ operating in predominantly defined contribution pension funds $(84.5 \%)$.

\subsection{Relationship between Pension Governance, Regulations and Leadership}

Simple regression analyses were conducted to measure the relationship between pension regulations, governance and leadership. The results, reported in Table 2 indicate that pension regulations are significantly positively related to pension governance $(r=0.199, p<0.01)$ and leadership $(r=0.240, p<0.01)$ thus confirming hypotheses 1 and 5. These influences are however very small: $6 \%$ in the variance of pension governance $\left(\mathrm{R}^{2}=\right.$ $0.064)$ and almost $10 \%$ in the case of pension plan leadership $\left(\mathrm{R}^{2}=0.096\right)$. These results show that pension regulations influence the way pension plans are governed and led. This result is supported by similar findings by Clark and Urwin (2009). The empirical results further reveal a positive relationship between pension governance and leadership $(0.32, p<0.05)$. Clark and Urwin (2009) reported similar findings and concluded that the two variables are related due to their association with the optimal allocation of resources, staffing; framing of delegated responsibilities; showing sensitivity to pension plan mission statements, setting investment targets, attending to the culture of the organization; and issues of accountability and performance measurement. Another reason for the close relationship between the three variables is that in Kenya, the RBA Act (2000) gives directions on pension plan governance and leadership. 
members on pension plan governance. The results of these analyses are reported in tables 3, 4 and 5. The results (table 3 ) show that the number of members in a pension plan is not significantly related to the plan's governance practices. This could be attributed to the fact that the RBA Act (2000) provides for the same number of trustees (governing board of the pension plan) regardless of the number of members in the pension plan. Table 3 further discloses that the pension plan design is not significantly related to the plan's governance practices. This means that whether the pension plan is operated as a DB or DC is not related to the way the fund is governed. This could be attributed to the fact that pension plan regulations (RBA, 2000) provide for the same governance code regardless of the pension plan design.

The results however reveal that the age of members influences plan governance significantly $(r=0.013, p>$ 0.05). Pearson correlation coefficients were calculated to assess whether these relations are positive or negative. This analysis reveals that the relationship is positive $(r=0.10, p>0.05)$, but not significant. The Scheffé test (table 5) however shows that there is a significant difference in the way a pension plan is governed when members are between 31 and 40 years old compared to the other age groups. The empirical results in table 4 reveal that pension plans, where the majority of the members are between the ages 31 to 40 , are better governed than the other age groups (mean score $=4.81$ on a five-point scale). Pension plans with a majority membership between the ages of 21 and 30 years had a governance score of 4.67 compared to 4.79 where members are older than 41 years. It therefore appears that pension plans of middle-aged members ( 31 to 40 years old) are perceived to be better governed compared to the other age groups. This can be attributed to the fact that these pension plans have fewer benefit payouts than those with older members, and their pension leaderships are more experienced compared to those with younger members. This result confirms the lifecycle pattern observed in pension plans by Clark (2004). According to Clark (2004), the lifecycle theorem views pension plans with younger members as less robust in their operations due to low resources in the pension plan. As the membership ages, contributions, managerial experiences and investments increase resulting to pension plans increasing their returns significantly. The increase in returns and the pension assets value makes the members to be more sensitive of the governance practices. As membership ages further, pension plans record lower returns as they are confronted with higher benefit payouts and consequent conservatism in the investment of funds, which lead to less interest in the governance aspect of the pension plan.

\subsection{Relationship between Membership Age, Pension Design, Number of Members and Leadership}

Main effects ANOVA were conducted to test the relationship between membership age, pension plan design, number of members and the pension plan leadership. The results of these analyses are reported in Table 6 and show that the number of members, pension plan designs and membership age do not influence leadership significantly thus failing to confirm hypotheses 2,3 and 4 . This means that the number of members and their ages, and whether it is a DB or DC fund do not exert an influence on how the fund is led. Although no comparable study could be reviewed, the empirical result suggest that fund leadership should be exercised with diligence, stewardship and commitment regardless of the age of the members, pension plan design or number of members.

\section{Theoretical and Managerial Implications of the Study}

The most important results of the study are the following:

- Pension regulations influence the way pension plans are led, as better leadership is observed in pension plans that adhere to regulations.

- Pension regulations influence the way pension plans are governed, as better governance is observed in pension plans that adhere to regulations.

- Membership ages influences pension plan governance, as pension plans with more middle-aged, 31 to 40 year old members, are perceived to be better governed compared to the other age groups.

The empirical results revealed that adherence to pension regulations improve pension plan leadership. It is recommended that managers adhere to the following regulations in order to improve pension plan leadership: regular monitoring of the performance of service providers; effective regulation of compliance costs; limiting the size of the pension plan board; conducting regulatory meetings with service providers; separation of pension plan management from employer management and maintaining a clear investment policy. By doing so, the following leadership elements will be achieved: complete honesty in sharing information with members; CEO commitment to the pension plan; the maintenance of an effective performance management system; compliance with RBA levies; adherence to RBA financial reporting regulations and the granting of full discretion to fund managers.

Why should these leadership elements be pursued? According to Clark and Urwin (2009) honest sharing of information ensures proper utilisation of pension plan authority, avoidance of conflict of interest and promotes transparency and openness in decision making. An effective CEO, according to Teisseire (2009), represents the interest of the pension plan in the board of the sponsoring company. Appropriate pension leadership is performance-oriented and maintains independent performance measurement systems (Ambatchsheer et al. 2008). Everybody in the pension plan, including external consultants, then would strive to achieve clear performance objectives.

Sound leadership ensures that pension plans avoid penalties and reduction of the fund's wealth by complying with regulatory levies (Whitehouse, 2000). Effective pension plan leaders engenders trust in investment managers to such an extent that full discretion in investment decisions can be granted to these managers. This 
leads to investment and administrative efficiencies according to Tang and Mitchell (2008), Bikker and Dreu (2009) and Chan-Lau (2005). Against this background, it is important that leadership in pension plans be enhanced, to reap the mentioned benefits.

The empirical results revealed that pension plans with membership in the 31 to 40 years age bracket are perceived to be better governed. This finding should be interpreted against the finding by Njuguna (2010) that smaller pension plans in Kenya appear to be more financially efficient than bigger ones. Managers should therefore keep their pension plans within manageable limits and focus more aggressively during recruitment on members aged 31 to 40 years to improve pension governance.

\section{Limitations of the Study and Direction for Future Research}

Due to the absence of existing instruments to measure the variables investigated in the study, particularly as far as pension plans are concerned, self constructed instruments were used. Some of these instruments produced low reliability coefficient, for example leadership $(a=0.56)$ and governance $(a=0.52)$. The instruments however reflected the Kenyan situation relevant to the study. Additionally, the study did not investigate the effect of governance on financial performance of the pension plans. Future research agenda should investigate the effect that the pension plan governance and leadership have on financial performance of the pension plans.

\section{Conclusion}

Effective pension fund governance involves the processes and decision making structures that ensure appropriateness of goals, information management procedures that support the goals, compliance with pension regulations and the pension fund's stakeholders' collectivism. To achieve efficient pension fund governance trustees should be allowed the opportunity to initiate action in response to their needs and preferences, adapt swiftly to changed situations with minimal interference from policy makers and therefore reconcile economic efficiency with equity stakeholders. In other words, the design, administration and management of pension funds should be closely attuned to the often-competing interests of those directly involved. To improve pension fund governance, practical pension laws should be crafted that focus on improvement of the leadership practices.

\section{References}

Ambachtsheer, K. (2001). A Framework for Public Pension Fund Management. Public Pension Fund Management Conference. World Bank. [Online] Available: www1.worldbank.org/finance/assets/images/Keith_Ambachtsheer.ppt (December 12, 2010)

Ambachtsheer, K. (2007). The three grades of pension fund governance quality: bad, better and best. OECD Publishing. Paris. [Online] Available: www.nasra.org/resources/Ambachtsheer\%2007.pdf (December 12, 2010)

Ambachtsheer, K., Capelle, R., \& Lum, H. (2006). Pension Fund Governance Today: Strengths, Weaknesses and Opportunities for Improvement. Financial Analysts Journal, October, 2006.

Ambachtsheer, K., Capelle, R., \& Lum, H. (2008). The pension governance deficit: Still with us. Rotman International Journal of Pension Management, (1), 14-21. http://dx.doi.org/10.3138/rijpm.1.1.14.

Asher, M., \& Nandy, A. (2006). Governance and Regulation of Provident and Pension Schemes in Asia. London: Edward Elgar (Chapter 2).

Bateman, H., \& Mitchell, O. (2004). New evidence on pension plan design and administrative expenses: the Australian experience. Journal of Pension Economics and Finance, (3), 63-76. http://dx.doi.org/10.1017/s1474747204001465.

Besley, T., \& Prat, A. (2005). Credible Pensions. Fiscal Studies, 26(1), 119-135. http://dx.doi.org/1111/j.1475-5890.2005.00006.x.

Bikker, J., \& Dreu, J. (2009). Operating Costs of Pension Funds: The impact of scale, governance and plan design. Journal of Pension Economics and Finance, (8), 63-89. http://dx.doi.org/10.1017/s1474747207002995.

Brady, J. (2008). Can 401 (k) Plans provide Adequate Retirement Resources? Pension Research Council. PRC WP2009-01. [Online] Available: http://ssrn.com/abstract=1317904 (December, 14, 2010)

Carmichael, J., \& Palacios, R. (2003). A Framework for Pension Fund Management. World Bank. $2^{\text {nd }}$ Public Pension Fund Management Conference, May 5-7. Washington DC. [Online] Available: www1.worldbank.org/.../Carmichael__Palacios--pension_frmwrk--doc.pdf (January 23, 2011)

CFA (2008). Code of Conduct for Members of a Pension Scheme Governing Body. CFA Institute. [Online] Available:

(February 14, 2011)

Chan-Lau, J. (2005). Pension Funds and Emerging Markets. Financial Markets, Institutions and Instruments, 14 (3). 107 - 133. http://dx.doi.org/10.1111/j.0963-8008.2005.00081.x.

Choi, J., Laibson, D \& Madrian, C. (2006). Reducing the Complexity Costs of 401 (k) Participation Through Quick Enrollment. Pension Research Council PRC WP2006-03. [Online] Available: www.nber.org/papers/w11979 (December 15, 2010)

Clapman P. et al. (2007). Committee on Fund Governance: Best Practice Principles. Committee on Pension Fund Governance. Stanford Institutional Investors' Forum. [Online] Available: www.law.stanford.edu/.../Clapman_Report-070316v6-Color.pdf (December 12, 2010) 
Clark, C. (2005). Executive Benefits: A Survey of Current Trends. [Online] Available: www.hr-topics.com/wire-usa/executive-benefits.htm (January 26, 2011)

Clark, G. (2004). Pension fund governance: expertise and organizational form. Journal of Pension Economics and Finance, (3) 233-53. http://dx.doi.org/10.1017/s1474747204001556.

Clark, G. (2006). Regulation of Pension Fund Governance: The Oxford Handbook of Pensions and Retirement Income. London: Oxford University http://dx.doi.org/10.1093/oxfordhb/9780199272464.001.0001

Clark, G., \& Urwin, R. (2008). Best Practice Investment Management: Lessons for Asset Owners from the Oxford-Watson Wyatt Project on Governance [Online] Available: http://ssrn.com/abstract=1019212 (February 14, 2011)

Clark, G., \& Urwin, R. (2009). Leadership, collective decision-making and pension fund governance. London: Oxford University Press. (Chapter 6).

Clark, R., \& Mitchell, O. (2005). Reinventing the Retirement Paradigm. London: Oxford University Press. (Chapter 2).

Corbo, V., \& Schmidt-Hebbel, K. (2004). Macro-Economic Effects of Pension Reform in Chile: Pension Reforms, Results and Challenges. Central Bank of Chile. [Online] Available: $\mathrm{http}: / /$ pensionreforms.com/API/xml/Abstracts/72 (January 22, 2011)

Davis E. P. (2005). The role of pension funds as institutional investors in emerging market economies. Korean Development Institute Conference. [Online] Available: http://www.brunel.ac.uk/9379/efwps/05-18.pdf (February 15, 2011)

Dias, L. (2006). Governance in Brazilian Pension Funds. bepress Legal Series. Working Paper 1447. [Online] Available: http://law.bepress.com/expresso/eps/1447 (December 15, 2011)

Dovi, E. (2008). Boosting Domestic Savings in Africa. Rom Africa Renewal, 22 (3). 12 - 26.

EBRI. (2007). Retirement Income Statistics. Employee Benefits Research Institute. [Online] Available: http://www.ebri.org/publications/books/index.cfm?fa=databook (December 15, 2010).

Eijffinger, S., \& Shi, Z. (2007). EU Pension Fund Regulation: Why, Where and How to Continue. [Online] Available:

http://www.eurofound.europa.eu/eiro/2011/02/articles/p11102019i.htm?utm_source=EIRO\&utm_medium=RSS \&utm_campaign=RSS (January 24, 2011)

Friedberg, L., \& Webb, A. (2004). Retirement and the Evolution of Pension Structure. Journal of Human Resources Management, XL (2). 281-308.

Galer, L. (2009). Prudent Person Rule: Standard for the Investment of Pension Fund Assets. OECD Publishing. [Online] Available: www.oecd.org/dataoecd/3/5/2084663.pdf (March 15, 2011)

Heijdra, J., \& Ligthart, E. (2006). The Macroeconomic Dynamics of Demographic Shocks," Macroeconomic Dynamics. Cambridge University Press, 10 (3). 349-370.

Hess, D., \& Impavido G. (2003). Governance of Public Pension Funds: Lessons from Corporate Governance and International Evidence. [Online] Available: http://ssrn.com/abstract=636473 (March 28, 2011)

Hu, Y., Stewart F., \& Yermo J. (2007). Pension Fund Investment and Regulation: An International Perspective and Implications for China's Pension System. OECD/IOPS Global Private Pensions Forum. Beijing. November pp.14-15. [Online] Available: www.oecd.org/dataoecd/51/29/39596265.pdf (March 2, 2011)

Hustead, E. (2008). Administrative Costs of State Defined Benefit and Defined Contribution Systems. Pension Research Council, PRC WP2008-18.

Impavido, G. (2005). Governance of Public Pension Funds: The importance of Residue Claimants. World Bank. Washington DC.

IOPS. (2007). Supervisory Education, Outreach and Communication, Including Training of Trustees. IOPS. Working Paper No. 2. [Online] Available: www.iopsweb.org/dataoecd/5/14/39126171.pdf (April 14, 2011)

IOPS. (2008). Supervisory Oversight of Pension Fund Governance. IOPS. Working Paper No. 8. [Online] Available: www.iopsweb.org/dataoecd/6/63/41269776.pdf (December, 15, 2010)

Kakwani, N., Sun, H., \& Hinz, R. (2006). Old-Age Poverty and Social Pensions in Kenya, International Poverty Center, Working paper No. 24. [Online] Available: www.ipc-undp.org/pub/IPCOnePager25.pdf (January 27, 2011)

Lerner, J., Schoar, A., \& Wongsunwai, W. (2007). Smart institutions, foolish choices: the limited partner performance puzzle. Journal of Finance (62): 731-64. http://dx.doi.org/10.1111/j.1540-6261.2007.01222.x

Lusardi, A., \& Mitchell O. (2008). Planning and Financial Literacy: How Do Women Fare? National Bureau of Economic Research. [Online] Available: http://www.nber.org/papers/w13750.pdf (January 27, 2011)

Madero, D., \& Lumpkin, S. (2007). A Review of the Pros and Cons of Integrating Pension Supervision with that of Other Financial Activities and Services. IOPS. Working Paper No. 1. [Online] Available: www.iopsweb.org/dataoecd/5/13/39126162.pdf (March 12, 2011) 
Moriarty, K., \& Zadorozny, L., (2008). Excellence in Pension Governance: Real Life. No Drama. [Online] Available: http://www.mecer.com/summary.htm?siteLanguage=100\&idContent=1329495. (15 August 2009).

Njuguna, G. (2010). Strategies to improve pension fund efficiency in Kenya. Unpublished doctoral thesis. Nelson Mandela Metropolitan University.

Nyce, S. (2005). The Importance of Financial Communication for Participation Rates and Contribution Levels in 401 (k) Plans. Pension Research Council. PRC WP 2005-3. [Online] Available: www.pensions-institute.org/workingpapers/WP2005-3.pdf (March 16, 2011)

Odundo, E. (2008). Supervision of Pensions: Kenyan Experience. [Online] Available: www.rba.go.ke/.../Presentation_Edward_Odundo_February2008.pdf (April 14, 2011)

OECD. (2009). Pension Fund Governance, Investment Strategies, and their Role in Corporate Governance. OECD Publishing. [Online]

Online] Available: www.fiap.cl/.../pension_fund_investment_and_its_role_on_corporate_governance_oecd_.pdf (April 14, 2011)

Pierce, J., \& Dunham, B. (1987). Organizational Commitment to Pre-employment Propensity and Initial Work Experience. Journal of Management, (13), 163 - 178. http://dx.doi.org/10.1177/014920638701300113.

Qureshi, I., \& McKay, J. (2007). The Prize of Global Governance. Benefits and Compensation International, (37) $8-15$.

Rauh, J. (2006). Investment and Financing Constraints: Evidence from the funding of corporate pension plans. Journal of Finance, (61), 289-315.

RBA Quarterly Report. (2010). Retirement Benefits Authority: Summary of Statistics. [Online] Available: http://www.rba.go.ke/docs/RBA-Summary-of-Investments-as-at-June-2010.pdf (April 14, 2011)

Rusconi, R. (2008). South African Institutional Investments: Whose Money is it Anyway?. [Online] Available: www.tresconsulting.co.za/Institutional\%20Investments\%20in\%20S\%20Africa\%20Jan\%20200 (April 12, 2011)

Saunders, M, Lewis, P., \& Thornhill, A. (2009). Research Methods for Business Students. New Jersey: Prentice Hall (Chapter 12).

STATISTICA Version 9.0. (2009). StatSoft Incorporated. [Online] Available: www.statsoft.com.

Stewart, F., \& Yermo, J. (2008). Pension Fund Governance: Challenges and Potential Solutions. OECD Working Papers on Insurance and Private Pensions, NO. 18, OECD Publishing http://dx.doi.org/10.1787/241402256531.

Stewart, F., \& Yermo, J. (2009). Pensions in Africa. OECD Publishing. [Online] Available: www.oecd.org/dataoecd/41/6/42052117.pdf (April 14, 2011)

Tang, N., \& Mitchell O. (2008). The Efficiency of Pension Plan Investment Menus: Investment Choices in Defined Contribution Pension Plans. Pension Research Council. Working Paper PRC WP 2008-02. [Online] Available: www.mrrc.isr.umich.edu/publications/papers/pdf/wp176.pdf (March 14, 2011)

Teisseire, D. (2009). Pension Governance. OECD Publishing. [Online] Available: www.ieba.org.uk/assets/.../documents/DAMIEN\%20TEISSEIRE.PDF (March 7, 2011)

Tharenou, P. (1993). A Test of Reciprocal Causuality for Absenteeism. Journal of Organizational Behaviour, (14), 269 - 290. http://dx.doi.org/10.1002/job.4030140306.

Useem, M., \& Mitchell, O. (2000). Holders of the purse strings: Governance and Performance of Public Retirement Systems. Social Science Quarterly, 81(2). 489 - 506.

Watson Wyatt Worldwide. (2007). Global Pension Assets Study, 2007. [Online] Available: www.towerswatson.com/research/(January 21, 2011)

Whitehouse, E. (2000). Administrative charges for funded pensions: an international comparison and assessment. OECD Publishing. [Online] Available: www.oecd.org/dataoecd/8/20/1816104.pdf (January 29, 2011)

Yang, T. (2005). Understanding the Defined Benefit versus Defined Contribution Choice. Pension Research Council. PRC WP 2005-4. [Online] Available: www.pensions-institute.org/workingpapers/WP2005-4.pdf (January 15, 2011)

Yang, T., \& Mitchell, O. (2005). Public Pension Governance, Funding and Performance: A Longitudinal Appraisal. Pension Research Council. PRC WP 2005-2. [Online] Available: www.pensionresearchcouncil.org/publications/document.php? (December 20, 2010)

Yermo, J. (2005). The Contribution of Pension Funds to Capital Market Development in Chile. OECD Publishing. [Online] Available: www.safp.c1/573/articles-3523_copyright.pdf (January 15, 2011)

Yermo, J. (2008). Governance and Investment of Public Pension Reserve Funds in Selected OECD countries. OECD Publishing. [Online] Available: www.oecd.org/dataoecd/26/53/40194872.pdf (January 14, 2011) 
Table 1. Demographic composition of the sample

\begin{tabular}{|l|l|r|r|}
\hline Variable & & $\mathbf{N}$ & \multicolumn{1}{l|}{$\%$} \\
\hline Gender & Male & 296 & 81.8 \\
\hline & Female & $\underline{66}$ & $\underline{18.2}$ \\
\hline & & $\underline{362}$ & $\underline{100}$ \\
\hline Age of respondents & $20-29$ years & 17 & 4.7 \\
\hline & $30-39$ & 261 & 72.1 \\
\hline & $40-49$ & 54 & 14.9 \\
\hline & $50-59$ & 26 & 7.2 \\
\hline & $60>$ & $\underline{4}$ & $\underline{1.1}$ \\
\hline & & $\underline{362}$ & $\underline{100}$ \\
\hline Position in pension plan & & & \\
\hline & Chairperson & 10 & 2.8 \\
\hline & Member & 23 & 6.4 \\
\hline & Trust secretary & 13 & 3.5 \\
\hline & Trustee & $\underline{316}$ & $\underline{87.3}$ \\
\hline & & $\underline{362}$ & $\underline{100}$ \\
\hline Occupational Level & Top management & 13 & 3.5 \\
\hline & Middle management & 349 & 96.5 \\
\hline & Lower management & $\underline{0}$ & $\underline{0}$ \\
\hline & & $\underline{362}$ & $\underline{100}$ \\
\hline Pension Design & Defined contribution & 306 & 84.5 \\
\hline & Defined benefit & $\underline{56}$ & 15.5 \\
\hline & & $\underline{362}$ & $\underline{100}$ \\
\hline Number of members & $<100$ & 82 & 22.7 \\
\hline & $101-200$ & 95 & 26.2 \\
\hline & $201-300$ & 72 & 19.9 \\
\hline & $401-500$ & 41 & 11.3 \\
\hline & $500>$ & $\underline{14}$ & $\underline{3.9}$ \\
\hline & & 362 & 100 \\
\hline
\end{tabular}

Table 2. The influence of pension regulations on pension governance and leadership - simple linear regression results

\begin{tabular}{|c|c|c|}
\hline \multicolumn{3}{|c|}{ Dependent variable: pension governance } \\
\hline \multicolumn{3}{|c|}{$\begin{array}{l}\mathrm{R}^{2}=0.064 \\
\mathrm{~F} \quad=24.709, \mathrm{p}<0.000 \\
\text { Standard error of estimate }=0.27260\end{array}$} \\
\hline Parameter & Regression coefficient & t-test p-value \\
\hline Intercept & 3.848 & $0.000^{*}$ \\
\hline Fund regulations & 0.199 & $0.000^{*}$ \\
\hline \multicolumn{3}{|c|}{ Dependent variable: pension plan leadership } \\
\hline \multicolumn{3}{|c|}{$\begin{array}{l}\mathrm{R}^{2}=0.096 \\
\mathrm{~F} \quad=38.237, \mathrm{p}<0.000 \\
\text { Standard error of estimate }=0.26484\end{array}$} \\
\hline Parameter & Regression coefficient & t-test p-value \\
\hline Intercept & 3.704 & $0.000^{*}$ \\
\hline Fund regulations & 0.241 & $0.000^{*}$ \\
\hline
\end{tabular}

Note: $*$ significant at $\mathrm{p}<0.01$ 
Table 3. Relationship between pension governance, membership age, fund design and fund size

\begin{tabular}{|l|c|c|}
\hline Independent variable & F-value & p-value \\
\hline Fund size & 0.70 & 0.608 \\
\hline Fund design & 0.65 & 0.420 \\
\hline Membership age & 4.33 & $0.013^{*}$ \\
\hline Degrees of freedom error $=354$ & \\
\hline
\end{tabular}

Note: $*=$ significant at $\mathrm{p}<0.05$ level

Table 4. Relationship between pension governance, membership age, pension design and number of members means and standard deviations

\begin{tabular}{|l|l|c|c|c|}
\hline \multicolumn{1}{|c|}{ Independent variable } & \multicolumn{1}{|c|}{ Category } & $\mathrm{N}$ & Mean & $\begin{array}{c}\text { Standard } \\
\text { deviation }\end{array}$ \\
\hline \multirow{5}{*}{ Fund size } & $<100$ & 82 & 4.81 & 0.25 \\
& $101-200$ & 94 & 4.82 & 0.33 \\
& $201-300$ & 72 & 4.79 & 0.23 \\
& $301-400$ & 58 & 4.79 & 0.24 \\
Fund design & $401+$ & 56 & 4.75 & 2.32 \\
\hline \multirow{3}{*}{ Member age } & Defined benefit & 306 & 4.80 & 0.27 \\
& Defined contribution & 56 & 4.77 & 0.35 \\
& $<20$ years & 0 & 0 & 0 \\
& $21-30$ & 35 & 4.67 & 0.46 \\
& $31-40$ & 293 & 4.81 & 0.26 \\
& $41+$ & 34 & 4.79 & 0.21 \\
\hline
\end{tabular}

Table 5. Relationship between pension governance, membership age, pension design and number of members SCHEFFÉ test

\begin{tabular}{|c|c|c|c|c|c|}
\hline \multicolumn{6}{|c|}{ Number of members } \\
\hline & $<100$ & $101-200$ & $201-300$ & $301-400$ & $401+$ \\
\hline$<100$ & & 0.999 & 0.997 & 0.995 & 0.781 \\
\hline $101-200$ & 0.999 & & 0.985 & 0.979 & 0.659 \\
\hline $201-300$ & 0.997 & 0.985 & & 0.999 & 0.926 \\
\hline $301-400$ & 0.995 & 0.979 & 0.999 & & 0.985 \\
\hline $401+$ & 0.781 & 0.659 & 0.926 & 0.985 & \\
\hline \multicolumn{6}{|c|}{ Membership age (in years) } \\
\hline & $21-30$ & $31-40$ & $41+$ & & \\
\hline $21-30$ & & $0.014 *$ & 0.190 & & \\
\hline $31-40$ & $0.014 *$ & & 0.893 & & \\
\hline $41+$ & 0.190 & 0.893 & & & \\
\hline
\end{tabular}

Note: $*$ significant at $0.05 \quad * *=$ significant at 0.01

Table 6. Relationship between membership age, pension design, number of members and pension leadership

\begin{tabular}{|l|c|c|}
\hline Independent variable & F-value & p-value \\
\hline Fund size & 0.40 & 0.834 \\
\hline Fund design & 0.01 & 0.918 \\
\hline Membership age & 1.96 & 0.142 \\
\hline Degrees of freedom error $=354$ & \\
\hline
\end{tabular}

Note: $*=$ significant at $\mathrm{p}<0.05$ level 


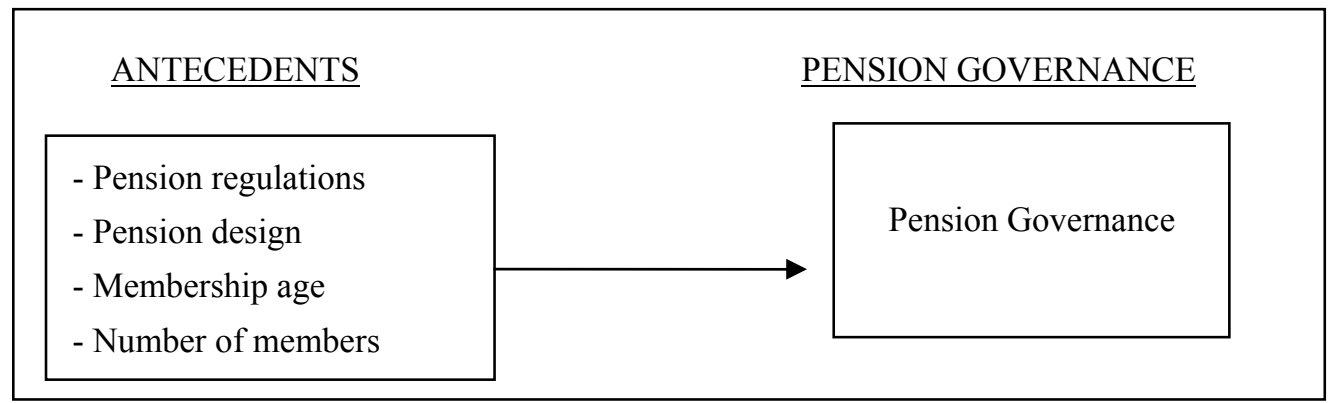

Figure 1. Conceptual model to improve pension plan governance

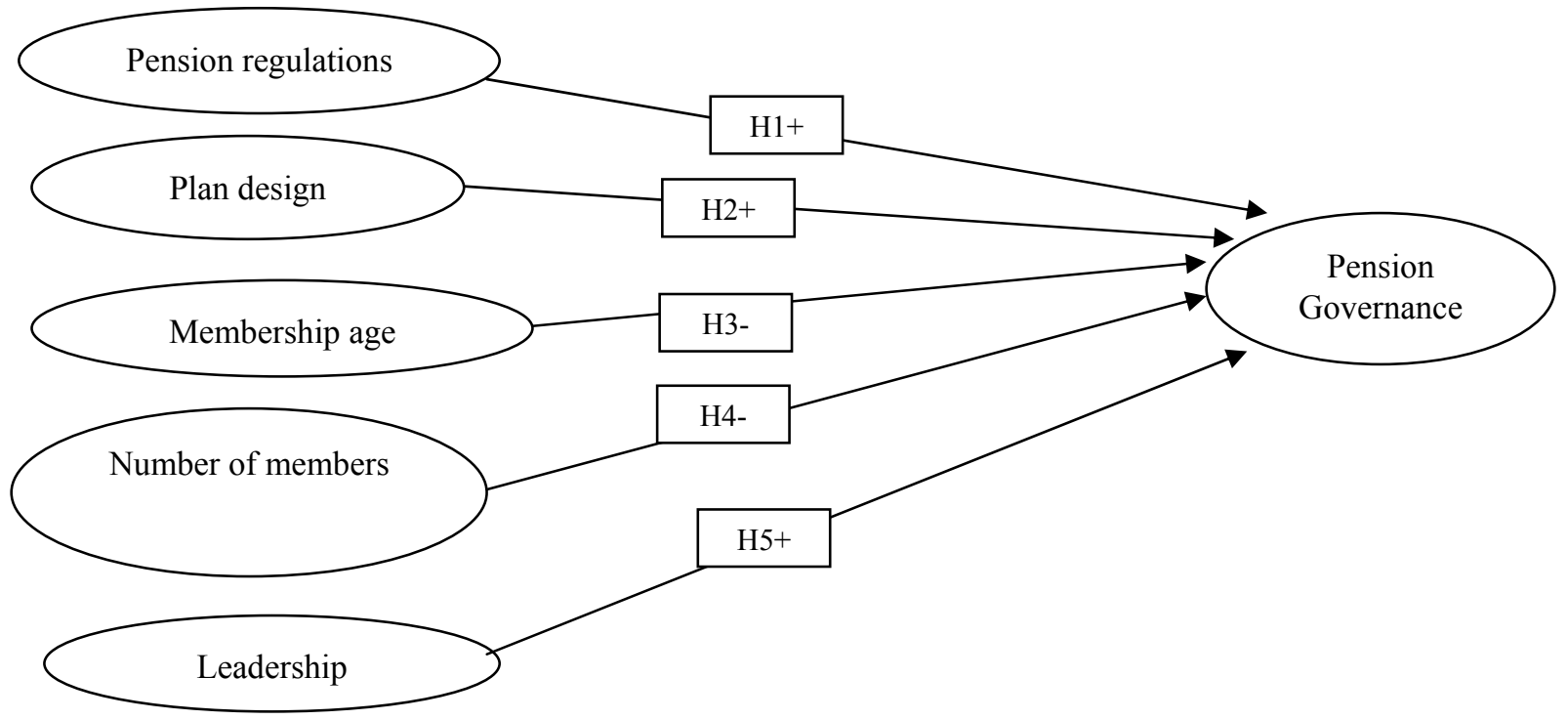

Figure 2. Hypothesized model to improve pension plan governance 